\title{
135. godišnjica rođenja Frana Bubanovića: slike iz života
}

\author{
K. Mlinac-Jerković, a,b V. Damjanović, ${ }^{a *}$ S. Kalanj-Bognara,b i J. Lovrića \\ a Zavod za kemiju i biokemiju, Medicinski fakultet, Sveučilište u Zagrebu, Hrvatska

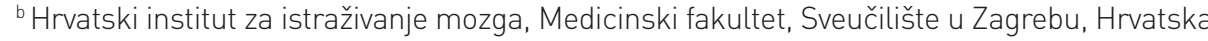

Ovo djelo je dano na korištenje pod Creative Commons Attribution 4.0 International License

\section{Sažetak}

U ovom radu prikazane su crtice iz života jednog od velikana hrvatskog prirodoslovlja, kemičara Frana Bubanovića. Ove 2018. godine obilježavamo 135 godina od njegova rođenja, 100 godina postojanja Zavoda za kemiju i biokemiju Medicinskog fakulteta Sveučilišta u Zagrebu, čiji je osnivač, te 100 godina od izdavanja njegove znanstveno-popularne knjige "Kemija živih bića". Kroz godine napisan je velik broj tekstova o njegovom doprinosu popularizaciji znanosti, znanstvenom opusu, njegovom nastavničkom pozivu kao i sveučilišnim udžbenicima. Ovim tekstom želimo se osvrnuti na pojedine zanimljive trenutke njegova života te prikazati nekoliko dosad neobjavljenih dokumenata i fotografija ustupljenih od njegove obitelji.

Ključne riječi

Fran Bubanović, medicinska kemija i biokemija, popularizacija znanosti

\section{Uvod}

Profesor Fran Bubanović (slika 1) jedan je od onih ljudi vrijednih pamćenja kojih se njihovi suradnici, poznanici i prijatelji trajno sjećaju i o njima govore godinama nakon njihove smrti. Nevjerojatna produktivnost i kreativnost ovog velikana ne samo hrvatske (bio)kemije već i popularizacije znanosti te nastave medicinske kemije i biokemije zabilježena je u mnogim tekstovima. ${ }^{1-14} \mathrm{Na}$ ovim stranicama koje ispisujemo povodom 135. godišnjice njegova rođenja nalazi se skroman pokušaj prikaza pojedinosti iz njegova bogatog života u kojem su njegovi profesionalni angažmani bili posve isprepleteni s privatnim životom. Stoga je teško razlučiti što mu je bio posao, a što osobno zadovoljstvo, budući da je uistinu živio kemiju.

\section{Crtice iz života}

Fran Bubanović rođen je u studenome 1883. godine u Sisku. Zanimljivo, iako njegove biografije mahom navode da je rođen 19. studenoga, u Matičnoj knjizi rođenih čuvanoj u Državnom arhivu u Sisku stoji zapis da je Bubanović rođen 18. studenoga, kao izvanbračno dijete majke Antonije Škavić i oca Antuna Škorjanca. Kumovi na krštenju su mu bili majčina sestra Marija Škavić i Mile Devčić. ${ }^{15}$ Potonji datum rođenja također nalazimo i u njegovoj osobnoj iskaznici izdanoj 1953. godine (slika 2). S majčinim prezimenom, Fran Skavić od 1890. do 1897. godine u Sisku pohađa pučku školu, a tek odlaskom na Sjemenište nadbiskupskog liceja u Zagrebu (7. i 8. razred gimnazije završio je u Sjemeništu) uzima prezime očuha Tome Bubanovića.

Godine 1901. Bubanović upisuje studij kemije i prirodopisa na Prirodoslovno-matematičkom odjelu Mudroslov-

*Autor za dopisivanje: dr. sc. Vladimir Damjanović

e-pošta: vladimir.damjanovic@mef.hr

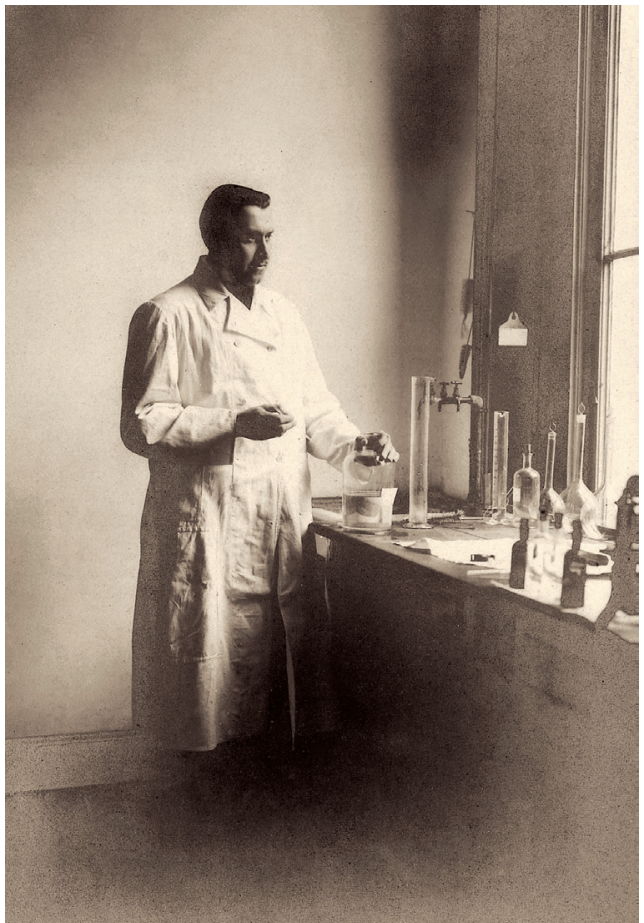

Slika 1 - Fran Bubanović u laboratoriju profesora Hamburgera u Groningenu, Nizozemska

Fig. 1 - Fran Bubanović in the laboratory of professor Hamburger in Groningen, Netherlands

nog fakulteta (današnji Filozofski fakultet) u Zagrebu. Uz predavanja iz kemije na matičnom fakultetu koje sluša kod profesora Gustava Janečeka, također dodatno sluša predavanja iz anorganske i organske kemije na Šumarskoj akademiji (današnjem Šumarskom fakultetu) kod dr. Srećka Bošnjakovića. Nakon uspješnog završetka studija 1905. godine postaje asistentom profesora Janečeka na Farma- 

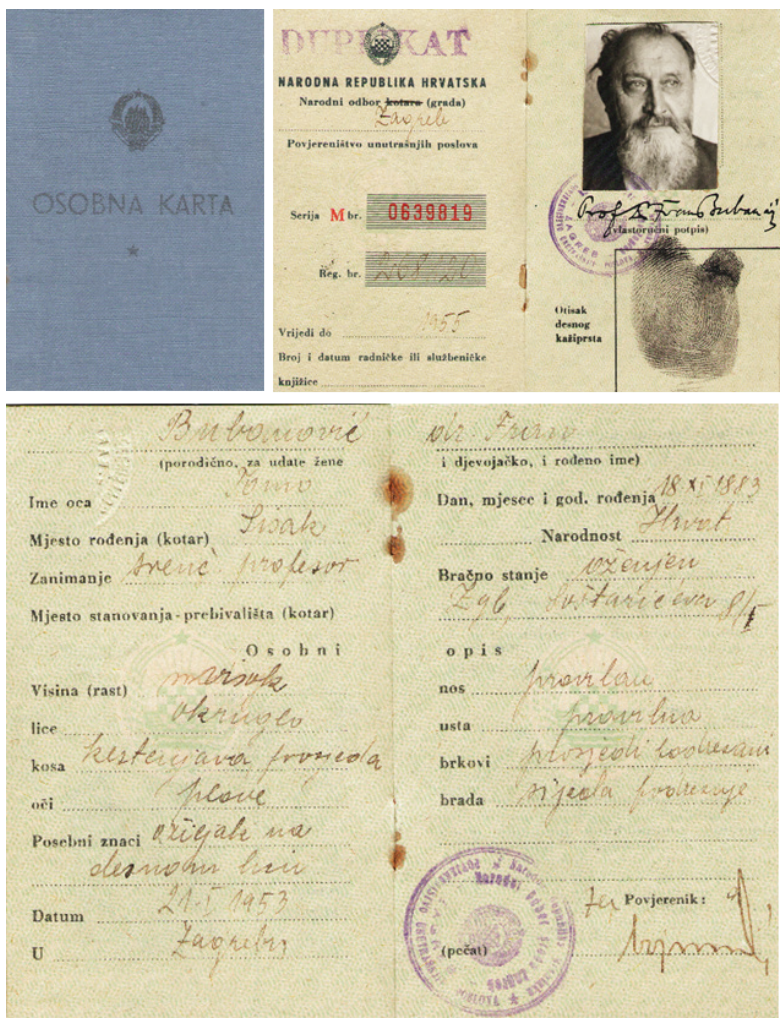

Slika 2 - Osobna iskaznica Frana Bubanovića

Fig. 2 - Fran Bubanović's personal identity card

ceutskom odjelu matičnog fakulteta..$^{3,4,6} \mathrm{~S}$ akademskom godinom 1907./1908., koju je obilježio veliki studentski štrajk, Bubanović biva premješten kao srednjoškolski na- stavnik kemije u Prvu gimnaziju u Zagrebu (koja se nalazila u sadašnjem prostoru muzeja Mimara), gdje je predavao kemiju i prirodopis akademskih godina 1907./1908., 1912./1913. te 1915./1916. ${ }^{16}$ U Prvoj gimnaziji Bubanović ujedno polaže Stručni ispit za srednjoškolskog profesora (1907. godine). Između 1908. i 1912. godine Bubanović biva premješten u tadašnju Kraljevsku realnu gimnaziju u Bjelovaru, ${ }^{3,5}$ gdje je predavao kemiju i prirodopis od 29. 8. 1908. kao "namjesni učitelj". ${ }^{17}$ Zahvaljujući tadašnjem županu bjelovarske županije Toši Georgijeviću kao i jednom bjelovarskom ljekarniku i narodnom poslaniku, mr. Josipu Werkleinu, ${ }^{18}$ Bubanović je 1909. godine dobio stipendiju i otišao na usavršavanje u laboratorij fiziološkog kemičara Hartoga Jacoba Hamburgera (1859. - 1924.) u Groningen u Nizozemsku. ${ }^{3,5}$ Bubanoviću je pažnju na Hamburgera skrenuo još Bošnjaković, na drugoj godini studija. Kod Hamburgera je Bubanović objavio svoj prvi znanstveni rad koji je iste godine kada je objavljen, 1910., prihvaćen u Beču i kao njegova doktorska disertacija. ${ }^{3-6}$ Bubanović je u Groningenu objavio još nekoliko zapaženih radova, ${ }^{2}$ te iako je očito bio posve zaokupljen znanstvenim radom, i dalje je pratio događanja u domovini i održavao kontakte s kolegama. Tome svjedoči i pismo (slika 3) Frana Bubanovića kolegi u Hrvatskoj u kojemu opisuje neizmjerno zadovoljstvo svojim napretkom i radom u Nizozemskoj te pruža potporu, ohrabrenje i prenosi stečena iskustva i daje savjete. Autori ne mogu sa sigurnošću utvrditi kome je pismo upućeno, no Bubanović u pismu navodi: "Vrlo mi je drago što Vam je pošlo za rukom osnovati vlastiti kem. laboratorij, jer se veselim svakom napredku na kem. području, a nadam se da će u našim hrvatskim kemičarskim prilikama Vaš laboratorij značiti doista korak naprijed iz monotonije, nerada i blata, u kojem se - hvala bogu i "dobrim" ljudima - te prilike nalaze." Pismo ujedno svjedoči i o njegovom iskrenom interesu za boljitak kemije u Hrvatskoj.

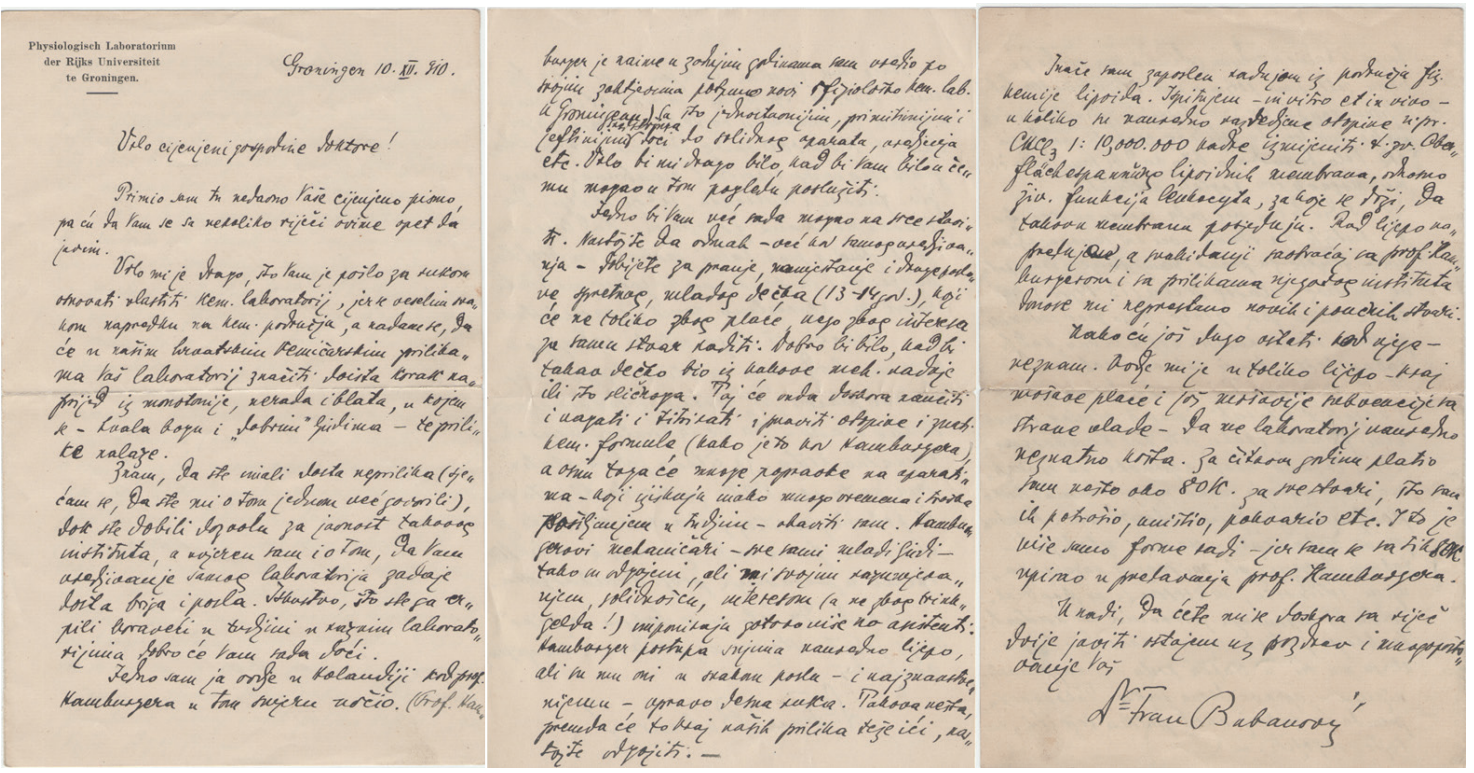

Slika 3 - Pismo Frana Bubanovića nepoznatom hrvatskom kolegi poslano iz Groningena

Fig. 3 - Fran Bubanović's letter to an unknown Croatian colleague sent from Groningen 


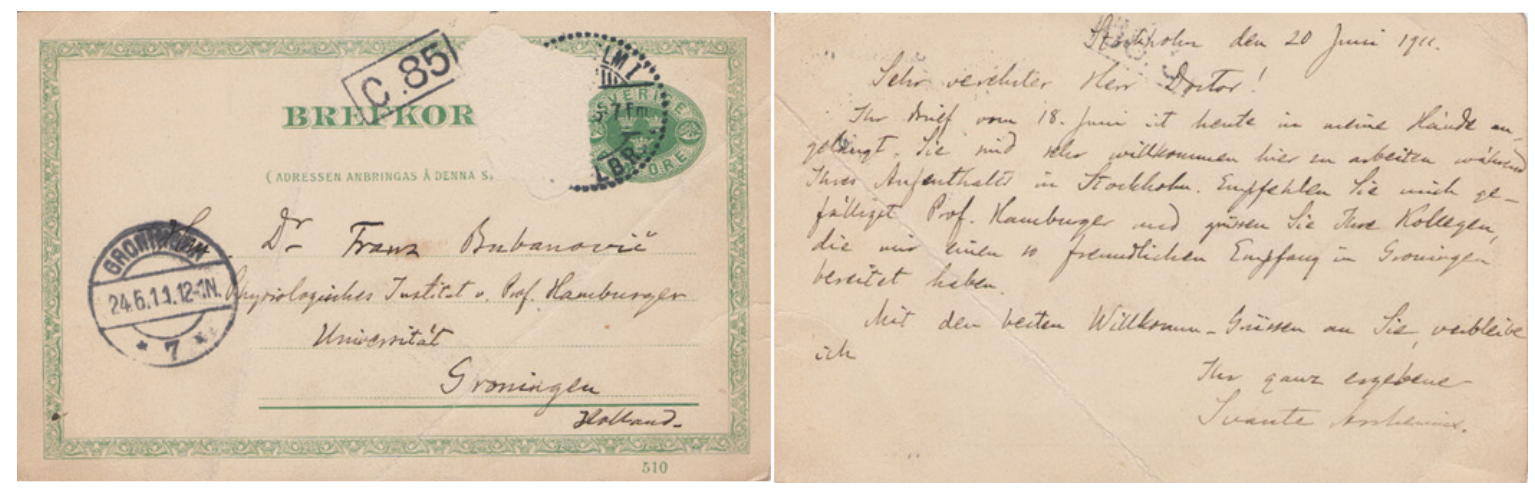

Slika 4 - Poziv za boravak na Nobelovom institutu za fizikalnu kemiju u Stockholmu koji je Franu Bubanoviću uputio nobelovac Svante Arrhenius

Fig. 4 - Invitation from Nobel prize laureate Svante Arrhenius to Fran Bubanović for training at Nobel Institute for Physical Chemistry in Stockholm

Zahvaljujući radu u Groningenu, švedski nobelovac Svante Arrhenius (1859. - 1927.) pozvao je Bubanovića na novoosnovani Nobelov institut za fizikalnu kemiju u Stockholmu (slika 4). Naime, pred kraj Bubanovićevog boravka u Groningenu, Arrhenius je na svom povratku iz Amerike došao u posjet tom sveučilištu te je tom prigodom održao i predavanje iz fizikalne kemije. ${ }^{18}$ Kako piše sam Bubanović, "...to sam tom prilikom zamolio Arrheniusa da mogu doći u njegov institut u Stockholmu. Jamačno se informirao o meni kod moga učitelja Hamburgera, pa sam naskoro primio od njega vijest da mogu odmah doći u njegov institut za fizikalnu kemiju u Experimentalfältetu kraj Stockholma. "18 U pismu koje spominje Bubanović (slika 4) tako stoji:

\section{Sehr verehrter Herr Doctor!}

Ihr Brief vom 18. Juni ist heute in meine Hände an gelingt. Sie sind sehr willkommen hier zu arbeiten während Ihres Aufenthalts in Stockholm. Empfehlen Sie mich gefälligst Prof. Hamburger und grüssen Sie Ihre Kollegen, die nür einen so freundlichen Empfang in Groningen bereitet haben.

Mit den besten Willkomen Grüssen an Sie verbleibe ich

Ihr ganz ergebener

Svante Arrhenius

(Vrlo poštovani gospodine doktore!

Vaše pismo od 18. lipnja danas je dospjelo u moje ruke. Ovdje ste vrlo dobrodošli raditi tijekom Vašeg boravka u Stockholmu. Kad Vam se pruži prigoda preporučite me prof. Hamburgeru i pozdravite Vaše kolege koji su mi pružili tako prijateljski doček u Groningenu.

S pozdravima dobrodošlice Vas pozdravljam, ostajem

Vaš posvećeni

Svante Arrhenius)
Bubanović u Stockholmu boravi nešto više od godinu dana, od 1911. do 1912. godine nakon čega se vraća u Hrvatsku.

Ta 1911. godina za Bubanovića je bila osobito značajna jer se iste godine i oženio Ivanom (Ivankom) pl. Malošeg (1888. - 1972.) (slika 5).

lako je Bubanović kod Arrheniusa boravio relativno kratko, ostali su vezani čvrstim i doživotnim prijateljstvom. Tome svjedoče brojna pisma koja su izmjenjivali, 8,10 kao i činjenica da su Arrhenius i njegova druga supruga Marija bili krsni kumovi Bubanovićevoj kćeri Julijani Svei (1913. - 2002.)
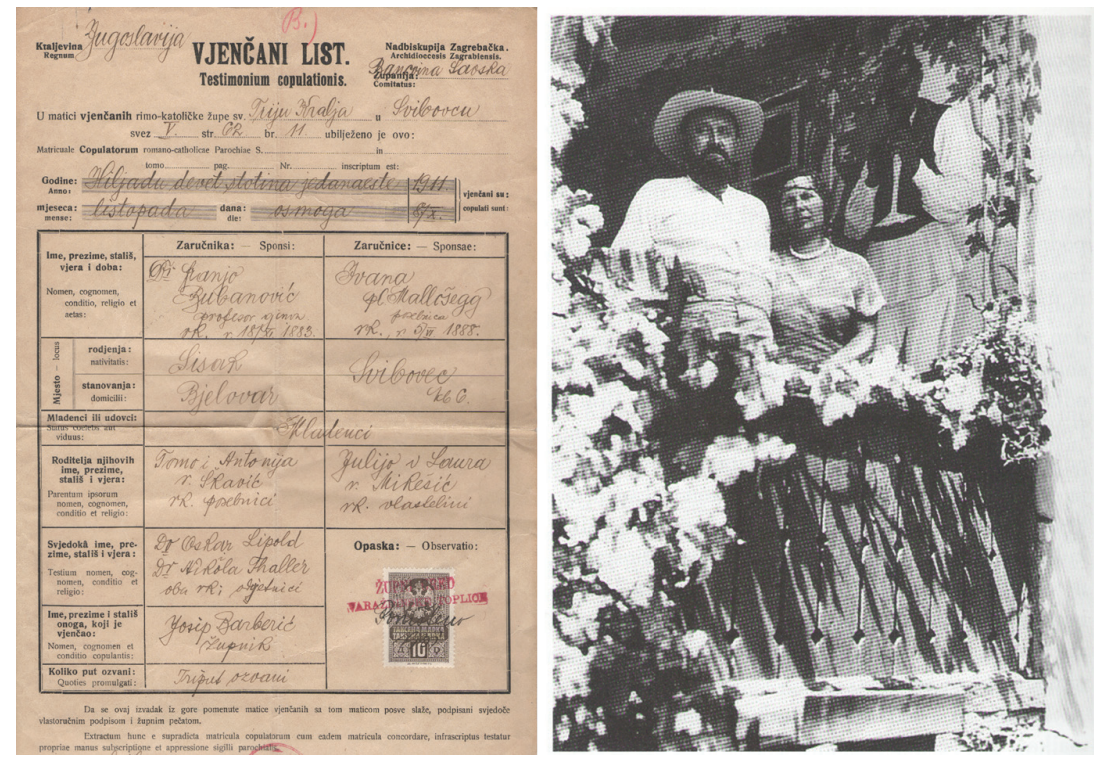

Slika 5 - Vjenčani list Frana Bubanovića i Ivane Malošeg te njihova zajednička fotografija na imanju u Gornjem Vrapču (fotografija objavljena u knjizi "Sav taj jazz - moja galerija slika i druge priče" njegova sina Aleksandra Bubanovića $)^{19}$

Fig. 5 - Fran Bubanović and Ivana Malošeg's marriage certificate and their photograph taken at their estate at Gornje Vrapče (the photograph is published in the book "All that jazz - my gallery of photographs and other stories" by his son, Aleksandar Bubanović) ${ }^{19}$ 
(slika 6). Osim kćeri Svee, bračni par Bubanović imao je i sina Aleksandra (1923. - 2009.), koji je postao poznati jazz gitarist.

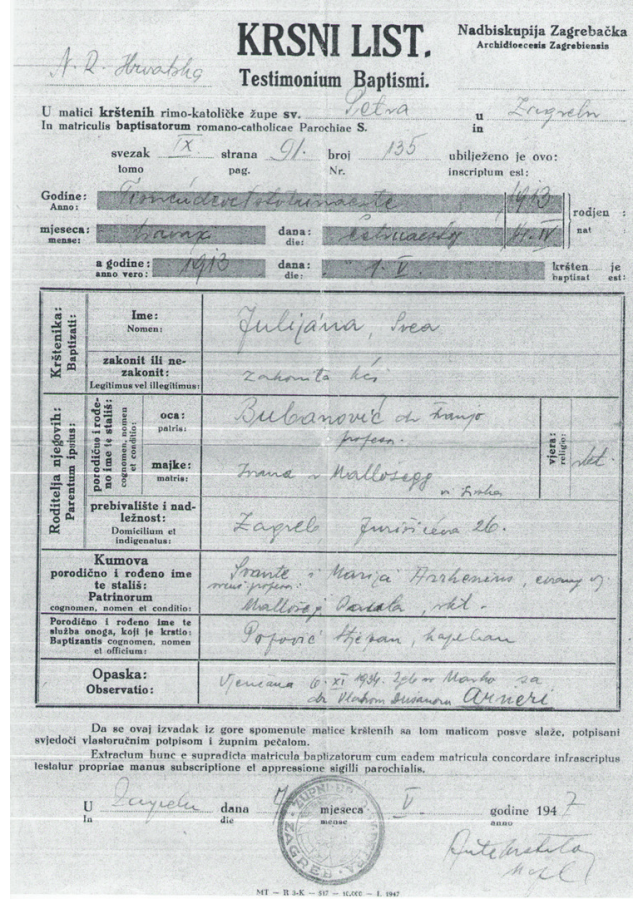

Slika 6 - Kopija krsnog lista Bubanovićeve kćeri iz koje je vidljivo kako joj je Svante Arrhenius bio krsni kum

Fig. 6 - A copy of the christening certificate of Bubanović's daughter in which it is stated that Svante Arrhenius was her godfather

Bubanović je nakon povratka s Nobelovog instituta nastavio raditi kao srednjoškolski profesor kemije i prirodopisa (u Bjelovaru i Zagrebu) sve do 1917. U tom je vremenu (1914. godine) i habilitirao na Sveučilištu u Zagrebu na temelju radova proizašlih iz suradnje s Arrheniusom kao i nekih samostalnih radova. ${ }^{5,12}$ Razlog što 1917 . godine Bubanović prestaje biti srednjoškolskim nastavnikom jest ostvarenje dugogodišnje težnje hrvatske intelektualne sredine za osnivanjem Medicinskog fakulteta u Zagrebu. Upravo je Bubanović bio odabran da se pripremi za osnivanje i vođenje Medicinsko-kemijskog zavoda (danas Zavoda za kemiju i biokemiju) u sklopu novoosnovanog Medicinskog fakulteta Sveučilišta u Zagrebu. ${ }^{5} \mathrm{U}$ tu svrhu Bubanović je poslan u Beč kod poznatog medicinskog kemičara profesora Otta von Fürtha (1867. - 1938.). Uz boravak u laboratoriju profesora Fürtha, također i iskustvo koje je Bubanović stekao za vrijeme svojeg boravka u Groningenu zacijelo je uvelike doprinijelo i olakšalo Bubanoviću ispunjavanje velikog zadatka stavljenog pred njega. Naime, za vrijeme boravka u Groningenu upravo je bila pri kraju gradnja i svečano se otvorio (slika 7) Hamburgerov novi fiziološki institut u sklopu tamošnjeg Medicinskog fakulteta. Tako je Bubanović, kako sam kaže, bio "sudionik uređivanja naučnoga instituta, koji je po priznanju mnogobrojnih stručnjaka bio jedan od najmodernijih u Evropi... U tom institutu, a pod vodstvom profesora Hamburgera uputio sam se i ja u metode tih istraživanja i u naučni rad uopće... Profesor je Hamburger svoj pomoćni personal (služitelje) odgojio tako, da nisu to bili kao u većini slučajeva kod nas neki podvornici za čišćenje instituta, nego sve mahom mehanici." ${ }^{18}$ Da ga se takva organizacija tamošnjeg instituta duboko dojmila, vidljivo je i iz već spomenutog pisma hrvatskom kolegi (slika 3), jer je već tada, 1910. godine, davao savjete kako organizirati kemijski laboratorij: "Nastojte da odmah - već od samog uređivanja - dobijete za pranje, namještanje $i$ druge poslove spretnog, mladog dečka (13 - 14 god.), koji će ne toliko zbog plaće, nego zbog interesa za samu stvar raditi. Dobro bi bilo, kad bi takav dečko bio iz kakove meh. radnje ili što sličnoga. Taj će onda doskora naučiti i vagati $i$ titrirati i praviti otopine i znati kem. formule (kako je to kod Hamburgera), a osim toga će mnoge popravke na aparatima - koji iziskuju jako mnogo vremena i troška pošiljanjem u tuđinu - obaviti sam. Hamburgerovi mehaničari - sve sami mladi ljudi - tako su odgojeni..."

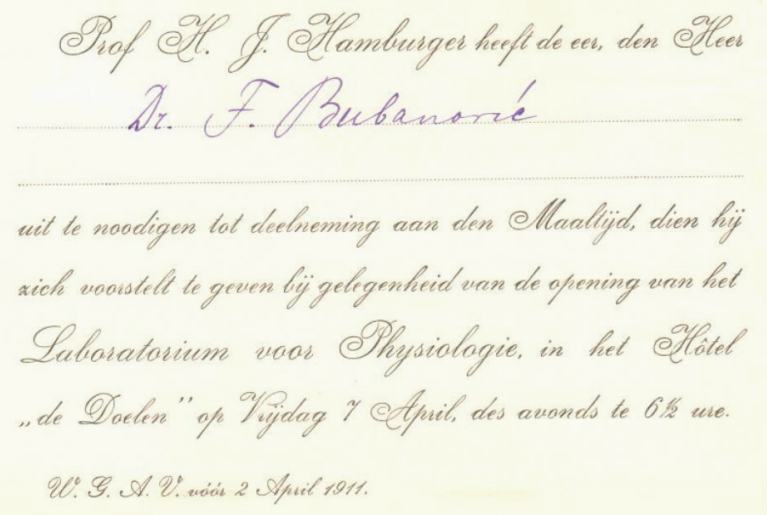

Slika 7 - Hamburgerov poziv za svečanost povodom otvaranja Laboratorija za fiziologiju upućen Franu Bubanoviću (iz travnja 1911. godine)

Fig. 7 - Hamburger's invitation to Fran Bubanović to attend a celebration regarding the opening of the Physiology Laboratory (from April 1911)

S Fürthom je Bubanović također imao priliku objaviti nekolicinu znanstvenih radova., ${ }^{2,12} \mathrm{Na}$ temelju tih radova te knjige "Kemija živih bića" Bubanović je 1919. godine imenovan izvanrednim, a zatim i redovitim profesorom medicinske kemije 1920. godine. ${ }^{5}$

Već tada, s nepunih 40 godina životne dobi, Bubanović je imao iza sebe nekoliko desetaka radova, kako znanstvenih i stručnih, tako i popularnih. ${ }^{2,3}$ Od popularno-znanstvenih knjiga svakako valja izdvojiti "Slike iz kemije", izdanu još 1917. godine, za koju je nagrađen novčanim iznosom iz Draškovićeve zaklade (slika 8) te "Kemiju živih bića" izdanu 1918. godine, dakle prije točno jednog stoljeća.

Razdoblje nakon samog osnivanja Medicinsko-kemijskog zavoda akademske godine 1918./1919. bilo je osobito intenzivno za Bubanovića, jer je vođenje i opremanje Zavo- 


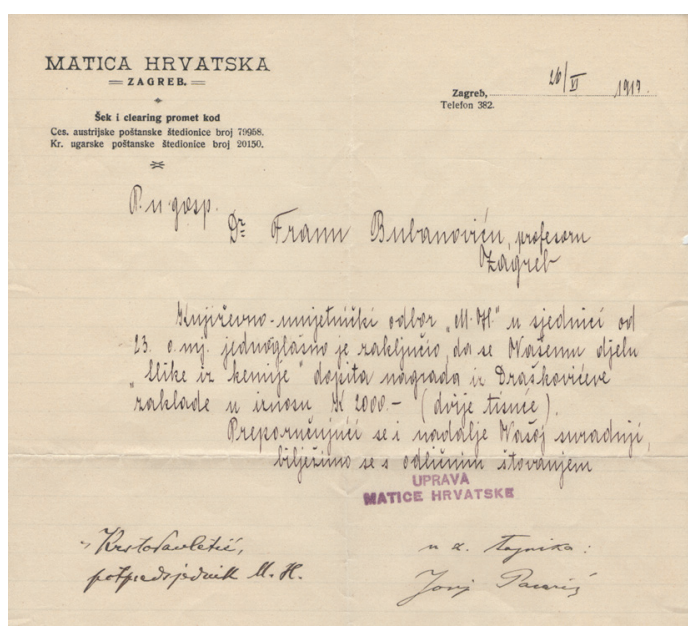

Slika 8 - Zapis Matice hrvatske o dodjeli nagrade iz Draškovićeve zaklade Franu Bubanoviću

Fig. 8 - A note from Matica Hrvatska regarding the Drašković Foundation Award to Fran Bubanović

da bio iznimno zahtjevan posao. Svi ti napori svakako su urodili plodom, jer se navodi da je Zavod uskoro postao najmoderniji sveučilišni kemijski zavod u Hrvatskoj s predavaonicom, praktikumom, laboratorijima i knjižnicom..$^{5,9}$

U razdoblju koje je uslijedilo, Bubanovićev žar i predanost poslu nimalo se nisu umanjili, a njegov puni nastavnički potencijal tek dolazi do izražaja. Bubanović tijekom sljedećih godina, uz daljnje izdavanje popularnih knjiga i mnoštva znanstveno-popularnih članaka, izdaje i sveučilišne udžbenike, ${ }^{3,9,12,13}$ a u dva navrata čak obnaša i dužnost dekana Medicinskog fakulteta (ak. god. 1921./1922. i 1930./1931.). Između 1941. i 1945. godine Bubanović biva prisilno umirovljen zbog pripadništva masonskom redu te tih nekoliko godina provodi, kako kaže njegov sin "u selu Mikulići kraj Zagreba...pa se potpuno povukao u anonimnost umirovljenika koji je s mjesečnom mirovinom uskoro mogao kupiti samo dva kilograma soli". 6,18 Nakon završetka Drugog svjetskog rata, Bubanović se ponovno aktivira na Sveučilištu te se vraća na Medicinski fakultet, gdje predaje još devet godina. Umirovljen je 1954., dvije godine prije smrti.

Bez obzira na nevjerojatnu produktivnost i posvećenost poslu i pisanju, Bubanović je bio i obiteljski čovjek koji je imao mnoštvo prijatelja, mahom znanstvenika i umjetnika. ${ }^{3,19}$ Bubanović je bio velik ljubitelj umjetnosti (često u svojim djelima citira hrvatske pjesnike), a njegov nasljednik na Zavodu za kemiju i biokemiju Tomislav Pinter opisuje ga kao čovjeka koji "voli prijatelje i cijeni prijateljstvo. Rijetko je koji čovjek imao toliko prijatelja, i rijetko je tko sam bio prijatelj tolikim ljudima". ${ }^{3}$ Vikende bi Bubanović s obitelji, uz posjete brojnih prijatelja, provodio pod Sljemenom na svojem malom imanju u Gornjem Vrapču. Na imanju se nalazio vrt, vinograd, voćnjak i drvena kućica, u kojoj je Bubanović volio pisati, te u kojoj je i njegov bliski prijatelj, slikar Dušan Kokotović smjestio svoj atelje. ${ }^{19}$

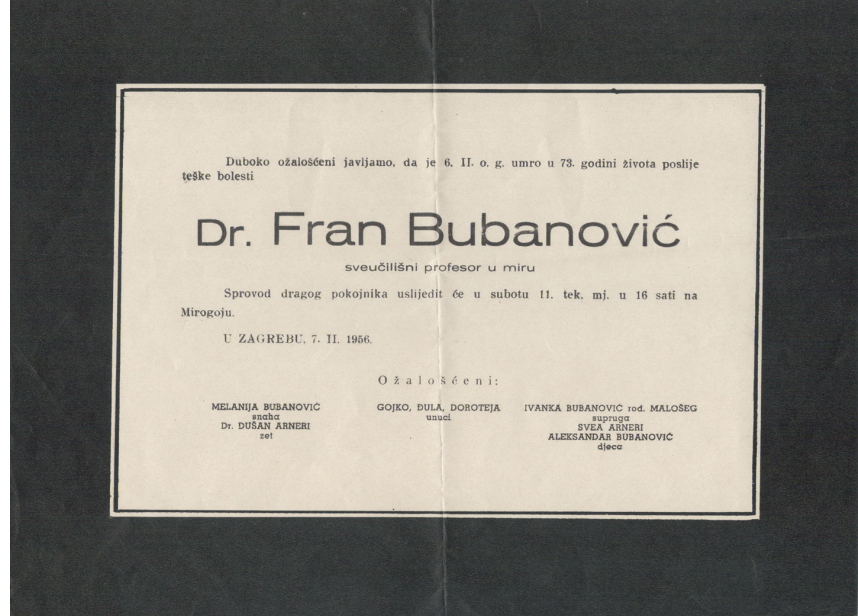

Slika 9 - Obavijest o smrti Frana Bubanovića

Fig. 9 - Death announcement of Fran Bubanović

Fran Bubanović preminuo je u veljači 1956. godine (slika 9), a pokopan je na zagrebačkom Mirogoju.

\section{Zaključak}

Fran Bubanović je kao dugogodišnji profesor na zagrebačkom Medicinskom fakultetu ostvario vrlo upečatljivu sveučilišnu karijeru. Osim njegova iznimna doprinosa hrvatskoj (bio)kemijskoj literaturi, svakako treba spomenuti i njegovu zapaženu međunarodnu znanstvenu karijeru i suradnju s pionirima fizikalno- i fiziološko-kemijske znanosti s kraja 19. i početka 20. stoljeća. lako kvantitetom možda ne spada među visoko produktivne znanstvenike, kvaliteta tih radova je iznimna. Uz to, njegovo znanje kemije i biokemije nije bilo rezervirano isključivo za akademsku sredinu, što ga do danas čini jednim od najvećih popularizatora znanosti na ovim prostorima. Velika kreativnost i produktivnost u profesionalnom životu nisu mu bile prepreka ostvarivanju bogatog privatnog života prožetog njegovom obitelji i dugogodišnjim prijateljstvima. lako nas je napustio prije više od šest desetljeća, još uvijek ga se često spominje, citira i navodi kao neponovljivog velikana hrvatske kemije. Njegov doprinos utemeljenju medicinske kemije u Hrvatskoj do danas je apsolutno nemjerljiv. Stoga prigodno možemo završiti ovaj rad upravo Bubanovićevim citatom koji se tiče njegovih učitelja kemije Janečeka, Bošnjakovića, kao i Hamburgera i Arrheniusa, koji su osim presudnog utjecaja na Bubanovića ostavili dubokog traga i u svjetskoj znanosti: "Kad bi mi sudbina dala da još jednom budem mlad i da tražim puteve za pristup u kemijsku nauku, to ne bih mogao zaželjeti drugih učitelja od njih". ${ }^{18}$

\section{ZAHVALA}

Zahvaljujemo dr. sc. Dorothei Sesardić, unuci Frana Bubanovića (kćeri Aleksandra Bubanovića), na velikodušno ustupljenim dokumentima. 


\section{Literatura \\ References}

1. J. Mikšić, Prof. Dr. Fran Bubanović (prigodom pedesetgodišnjice), Farm.Vjesn. 22 (1933) 804-812.

2. T. Pinter, Naučni rad prof. Bubanovića, Farm.Vjesn. 22 (1933) 812-833.

3. T. Pinter, Sedamdeseta godišnjica prof. dra. Frana Bubanovića (19. XI. 1983.-19. XI. 1953.), Farm. Glasn. 3 (1954) 91-100.

4. T. Pinter, Prof. Dr. Fran Bubanović (1883-1956), Croat. Chem. Acta 29 (1957) 53-62.

5. D. Grdenić, Prvi hrvatski kemičari, Kem. Ind. 42 (6) (1993) 171-186.

6. M. Tarle, Fran Bubanović, nestor hrvatske biokemije, Priroda 86 (1996) 38-42.

7. S. Paušek Baždar, Mjesto i uloga prirodoslovca Frana Bubanovića u hrvatskoj intelektualnoj sredini, u Dani hvarskog kazališta, HAZU i Književni krug Split, Zagreb-Split, 2004, str. 374-381.

8. N. Raos, Bubanović i Arrhenius, Kem. Ind. 54 (6) (2005) 320-322.

9. N. Trinajstić, S. Paušek Baždar, Hrvatska kemija u XX. stoljeću. I. Razdoblje od početka stoljeća do 8. svibnja 1945. Kem. Ind. 56 (7-8) (2007) 403-416.

10. N. Raos, Letters of Svante Arrhenius to his former Croatian student, Bull. Hist. Chem. 33 (1) (2008) 12-16.

11. N. Raos, Povijesni osvrt na popularizaciju kemije u Hrvatskoj, Kem. Ind. 61 (5-6) (2012) 281-288.

12. K. Mlinac, Povodom 130. godišnjice rođenja prof. dr. Frana Bubanovića, Mef.hr - list Medicinskog fakulteta 32 (2) (2013) 119-122.

13. V. Damjanović, K. Mlinac-Jerković, S. Kalanj Bognar, J. Lovrić, Fran Bubanović: The Visionary of Medical Chemistry and Biochemistry in Croatia, Croat. Chem. Acta 90 (3) (2017) 509-514, doi: https://doi.org/10.5562/cca3157.

14. V. Damjanović, K. Mlinac-Jerković, S. Kalanj Bognar, J. Lovrić, Nastava kemije i biokemije na Medicinskom fakultetu u Zagrebu u doba Frana Bubanovića, Liječn. Vjesn. 140 (5-6) (2018) 174-179, doi: https://doi.org/10.26800/LV-140-5-623

15. Državni arhiv u Sisku, Matična knjiga rođenih župe Sisak: 1879.-1889.

16. B. Dakić (ur.), Spomenica Prve gimnazije u Zagrebu: 1854.2004., Prva gimnazija, Zagreb, 2004.

17. Izvještaji ravnateljstva Kraljevske realne gimnazije u Bjelovaru o školskoj godini 1908./1909., 1911./1912. i 1912./1913.

18. F. Bubanović, Moji učitelji kemije, Farm. Vjesn. 26 (3) (1936) 68-82.

19. A. Bubanović, Sav taj jazz - moja galerija slika i druge priče, Durieux, Zagreb, 2005.

\section{SUMMARY}

$135^{\text {th }}$ Birth Anniversary of Fran Bubanović: Notes from His Life Kristina Mlinac-Jerković, ${ }^{a, b}$ Vladimir Damjanović, ${ }^{*}$ Svjetlana Kalanj-Bognar, ${ }^{a, b}$ and Jasna Lovrića

This paper gives an account of some details in the life of one of the most remarkable people in Croatian natural sciences, chemist Fran Bubanović. In 2018, we commemorate his $135^{\text {th }}$ birth anniversary, $100^{\text {th }}$ anniversary of the Department of Chemistry and Biochemistry founded by Bubanović at the School of Medicine, University of Zagreb, and a 100 years since the publishing of his popular science book "The Chemistry of Living Beings". Throughout the years, numerous texts have been written regarding his contribution to science popularization, scientific work, his teaching career, as well as his university textbooks. In this text, we attempt to reflect on some specific moments in his life, as well as present several unpublished documents and photographs donated by his family.

\section{Keywords}

Fran Bubanović, medical chemistry and biochemistry, science popularization

a Department of Chemistry and Biochemistry, School of Medicine, University of Zagreb, Croatia

${ }^{\mathrm{b}}$ Croatian Institute for Brain Research, School of

Medicine, University of Zagreb, Croatia
Review

Received April 26, 2018 Accepted May 17, 2018 